\title{
Dichlorophosphoranides Stabilized by Formamidinium Substituents
}

\author{
Anatoliy Marchenko, Georgyi Koidan, Anastasiya Hurieva, Eduard Rusanov, \\ Alexander B. Rozhenko, and Aleksandr Kostyuk $(\mathbb{D}$ \\ Institute of Organic Chemistry National Academy of Sciences of Ukraine, Murmanska 5, 02660 Kyiv 94, Ukraine \\ Correspondence should be addressed to Aleksandr Kostyuk; a.kostyuk@yahoo.com
}

Received 10 December 2019; Accepted 16 January 2020; Published 13 February 2020

Academic Editor: Mariateresa Giustiniano

Copyright ( 92020 Anatoliy Marchenko et al. This is an open access article distributed under the Creative Commons Attribution License, which permits unrestricted use, distribution, and reproduction in any medium, provided the original work is properly cited.

Dichlorophosphoranides featuring $N, N$-dimethyl- $N^{\prime}$-arylformamidine substituents were isolated as individual compounds. Dichlorophosphoranide 9 was prepared by the multicomponent reaction of $C$-trimethylsilyl- $N, N$-dimethyl- $N^{\prime}$-phenylformamidine and $N, N$-dimethyl- $N^{\prime}$-phenylformamidine with phosphorus trichloride. Its molecular structure derived from a single-crystal X-ray diffraction was compared to the analogous dibromophosphoranide prepared previously by us by the reaction of phosphorus tribromide with $N, N$-dimethyl- $N^{\prime}$-phenylformamidine. It was shown that a chlorophosphine featuring two $N, N$ dimethyl- $N^{\prime}$-mesitylformamidine substituents reacted with hydrogen chloride to form dichlorophosphoranide 11. Its molecular structure was also determined by X-ray analysis and compared with that of closely related dichlorophosphoranide $\mathbf{C}$.

\section{Introduction}

Phosphoranides A are hypervalent anionic phosphorus(III) compounds formally possessing a 10 -electron valence shell and a distorted pseudotrigonal bipyramidal arrangement at the phosphorus atom. The electronegative ligands at phosphines make nucleophilic addition possible to afford stable phosphoranides (Figure 1).

The first isolated phosphoranide has been prepared by the reaction of tetrapropylammonium bromide with phosphorus tribromide, and its structure has been unambiguously determined by a single-crystal X-ray diffraction study $[1,2]$. Later, tetrachlorophosphoranides and tetrafluorophosphoranides were prepared, with tetrafluorophosphoranide being the most stable derivative [3]. $\mathrm{N}$ heterocyclic carbenes are known to be suitable for stabilization of high-coordinated $\mathrm{P}$ atoms. The reaction of a sterically hindered $\mathrm{N}$-heterocyclic carbene with $\mathrm{PCl}_{3}$ in hexane affords a high yield of phosphoranide $\mathbf{B}$. The imidazoliumyl substituent efficiently stabilizes phosphoranides. Another example is phosphoranide $\mathbf{C}$ in which the imidazolium moieties serve for stabilization $[4,5]$. In our previous publication, we have described the synthesis of dibromophosphoranide 3 by the reaction of $N, N$-dimethyl- $N^{\prime}$-phenylformamidine 1 with phosphorus tribromide in a $3: 1$ ratio. Its structure was established by X-ray diffraction analysis. Based on DFT calculations, the mechanism for formation of phosphoranide $\mathbf{3}$ has been suggested (Scheme 1) [6].

The final step of the proposed mechanism is the reaction of dibromophosphine 2 with $N, N$-dimethyl- $N^{\prime}$-phenylformamidine. It should be noted that other P(III) halides, such as phosphorus trichloride, dichlorophosphines, and monochlorophosphines, do not react with the formamidines. Earlier, we were unable to check the mechanism, as dibromo(dichloro)phosphines featuring the formamidine substituent were unavailable. Recently, we have developed a method for the synthesis of $C$-trimethylsilyl- $N, N$-dialkyl- $N^{\prime}$ arylformamidines and studied their reactions with phosphorus trichloride and chlorophosphines. A set of chlorophosphines featuring two formamidine substituents were isolated as stable compounds [7]. We assumed that dichlorophosphines featuring the formamidine substituents can be prepared by this method as well. It will allow 


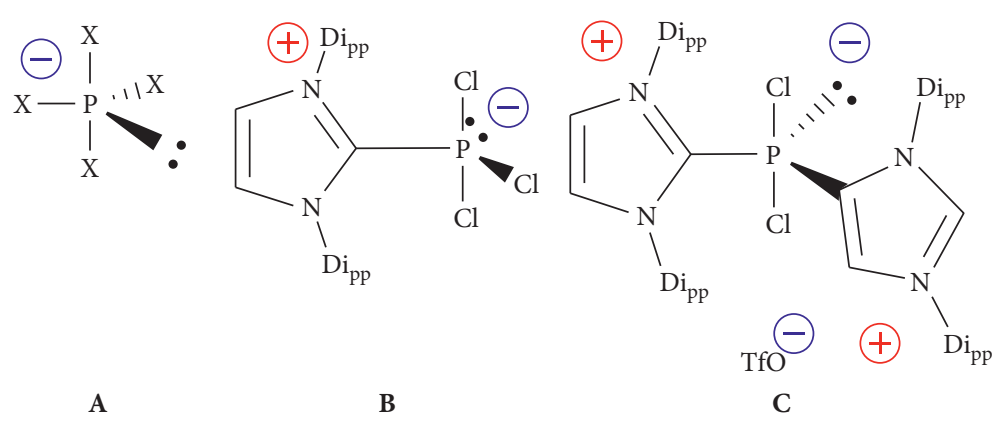

FIgURE 1: Examples of phosphoranides stabilized by $N$-heterocyclic carbene ligands.
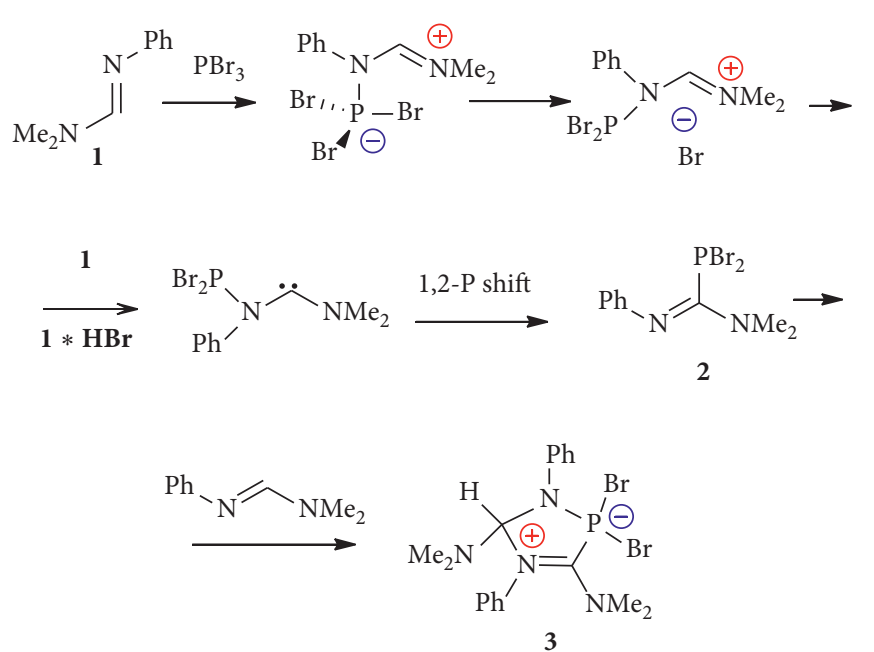

Scheme 1: Mechanism proposed for formation of dibromophosphoranide 3 .

investigation of the proposed mechanism and development of a method for the synthesis of phosphoranides.

\section{Materials and Methods}

All procedures with air- and moisture-sensitive compounds were performed under an atmosphere of dry argon in flamedried glassware. Solvents were purified and dried by standard methods. Melting points were determined with an electrothermal capillary melting point apparatus and were uncorrected. ${ }^{1} \mathrm{H}$ spectra were recorded on a Bruker Avance DRX $500(500.1 \mathrm{MHz})$ or Varian VXR-300 (299.9 MHz) spectrometer. ${ }^{13} \mathrm{C}$ NMR spectra were recorded on a Bruker Avance DRX $500(125.8 \mathrm{MHz})$ spectrometer. ${ }^{31} \mathrm{P}$ NMR spectra were recorded on a Varian VXR-300 (121.4 MHz) spectrometer. Chemical shifts $(\delta)$ are reported in $\mathrm{ppm}$ downfield relative to internal TMS (for ${ }^{1} \mathrm{H},{ }^{13} \mathrm{C}$ ) and external $85 \% \mathrm{H}_{3} \mathrm{PO}_{4}$ (for ${ }^{31} \mathrm{P}$ ). Chromatography was performed on silica gel Gerudan $\mathrm{SI}_{60}$. Elemental analyses were performed at the Microanalytical Laboratory of the Institute of Organic Chemistry of the National Academy of Sciences of Ukraine.

2.1. X-ray Structure Determination. Crystal data for 9: $\left(\mathrm{C}_{18} \mathrm{H}_{23} \mathrm{Cl}_{2} \mathrm{~N}_{4} \mathrm{P}\right), \quad M=397.29$, triclinic, space group $\mathrm{P}-1$, $\mathrm{a}=9.3377(2), b=9.9530(2), c=12.3654(3) \AA, \alpha=108.414(1)$, $\beta=106.412(1), \quad \gamma=101.860(1)^{\circ}, \quad V=989.57(4) \AA^{3}, \quad Z=2$, $d_{\mathrm{c}}=1.33, \mu 0.418 \mathrm{~mm}^{-1}, \mathrm{~F}(000) 416$, crystal size ca. $0.33 \times 0.47 \times 0.54 \mathrm{~mm}$. All crystallographic measurements were performed at $123 \mathrm{~K}$ on a Bruker Smart Apex II diffractometer operating in the $\omega$ scans mode. The intensity data were collected using Mo- $\mathrm{K}_{\alpha}$ radiation $(\lambda=0.71078 \AA$ ). The intensities of 22667 reflections were collected (4183 unique reflections, $R_{\text {merg }}=0.033$ ). Convergence for 9 was obtained at $R_{1}=0.0294$ and $\mathrm{wR}=0.058$ for 3520 observed reflections with $I \geq 3 \sigma(I) ; \mathrm{GOF}=0.9332, R_{1}=0.0360$, and $\mathrm{wR}=0.0617$ for all 4167 data, 226 parameters, and the largest and minimal peaks in the final difference map 0.34 and $-0.22 \mathrm{e} / \AA^{3}$.

Crystal data for 11: $\left(\mathrm{C}_{24} \mathrm{H}_{35} \mathrm{Cl}_{2} \mathrm{~N}_{4} \mathrm{P}_{1}\right), M=481.45$, orthorhombic, space group Pna2,$\quad \mathrm{a}=11.8655(3)$, $b=14.1280(3), c=15.3685(3) \AA, V=2576.31(10) \AA^{3}, Z=4$, $d_{\mathrm{c}}=1.241, \mu 0.333 \mathrm{~mm}^{-1}, \mathrm{~F}(000) 1024$, crystal size ca. $0.25 \times 0.27 \times 0.48 \mathrm{~mm}$. All crystallographic measurements were performed at $123 \mathrm{~K}$ on a Bruker Smart Apex II diffractometer operating in the $\omega$ scans mode. The intensities of 30253 reflections were collected (4944 unique reflections, $\left.R_{\text {merg }}=0.039\right)$. Convergence for $\mathbf{1 1}$ was obtained at $R_{1}=0.0287$ and $\mathrm{wR}=0.0484, \mathrm{GOF}=0.9187$ for $4259 \mathrm{ob}-$ served reflections with $I \geq 3 \sigma(I)$; $\mathrm{GOF}=0.9187, R_{1}=0.0363$, and $\mathrm{wR}=0.0525$ for all 4923 data, 285 parameters, the largest and minimal peaks in the final difference map 0.41 and $-0.31 \mathrm{e} / \AA^{3}$. The structures were solved by direct methods and refined by the full-matrix least-squares technique in the anisotropic approximation for non-hydrogen atoms using the SIR97 and Crystals program package $[8,9]$.

1,1-Bis(dimethylamino)- $N, N$-diisopropyl- $N^{\prime}$-4-mesitylphosphine-carboximidamide selenide (5a): To a frozen solution of $4 \mathrm{a}(1.31 \mathrm{~g}, 5 \mathrm{mmol})$ in $\mathrm{Et}_{2} \mathrm{O}(15 \mathrm{~mL})$, a solution of $\mathrm{PCl}_{3}(0.69 \mathrm{~g}, 5 \mathrm{mmol})$ in diethyl ether $(15 \mathrm{~mL})$ was added. The reaction mixture was allowed to warm to ambient temperature $\left(15^{\circ} \mathrm{C}\right)$ with stirring. The solvent was evaporated. Benzene $(5 \mathrm{~mL})$ was added to the residue, and then, a solution of dimethylamine $(900 \mathrm{mg}, 20 \mathrm{mmol})$ in benzene $(6 \mathrm{~mL})$ was added. The mixture was stirred for $15 \mathrm{~min}$, and selenium (500 mg, $6 \mathrm{mmol}$ ) was added. The resulting suspension was stirred for $1 \mathrm{~h}$ at $15^{\circ} \mathrm{C}$. The insolubles were filtered off and washed with benzene $(2 \times 5 \mathrm{~mL})$, and the filtrate was evaporated. The residue was purified by silica gel plate chromatography. Yield, 60\%. $R_{\mathrm{f}} \quad 0.2-0.45$ $\left(\mathrm{CH}_{2} \mathrm{Cl}_{2}\right.$-hexane $\left.1: 1\right)$, m.p. ${ }^{116}-117^{\circ} \mathrm{C} ;{ }^{31} \mathrm{P}\left\{{ }^{1} \mathrm{H}\right\} \quad \mathrm{NMR}$ $\left(202 \mathrm{MHz}, \mathrm{CDCl}_{3}\right): \delta=65.7\left(J_{\mathrm{PSe}}=793 \mathrm{~Hz}\right) \mathrm{ppm} ;{ }^{1} \mathrm{H} \mathrm{NMR}$ 
$\left(300 \mathrm{MHz}, \mathrm{CDCl}_{3}\right): \delta=2.10\left(\mathrm{~s}, 6 \mathrm{H}, \mathrm{CH}_{3}\right), 2.23\left(\mathrm{~s}, 3 \mathrm{H}, \mathrm{CH}_{3}\right)$, $2.84(\mathrm{~d}, J=2.7 \mathrm{~Hz}), 2.87\left(\mathrm{~s}, 18 \mathrm{H}, \mathrm{NCH}_{3}\right), 6.77(\mathrm{~s}, 2 \mathrm{H}, \mathrm{CH})$ ppm; ${ }^{13} \mathrm{C} \mathrm{NMR}\left(125.7 \mathrm{MHz}, \mathrm{C}_{6} \mathrm{D}_{6}\right): \delta=18.6\left(\mathrm{~s}, \mathrm{CH}_{3}\right), 20.2(\mathrm{~s}$, $\mathrm{CH}_{3}$ ), 37.9 (s, $\mathrm{CH}_{3}$ ), 39.8 (s, $\left.\mathrm{CH}_{3}\right), 126.1$ (s, ipso-C), 127.6 (s, CH), 129.9 (s, ipso-C), 145.3 (d, J=21 Hz, ipso-C), 150.5 (d, $J=155 \mathrm{~Hz}, \mathrm{CN})$; EI-MS 387-100\% $[M+2]^{+}$; elemental analysis calcd (\%) for $\mathrm{C}_{16} \mathrm{H}_{29} \mathrm{~N}_{4} \mathrm{PSe}$ (387.37) C 49.61, H 7.55, N 14.46, P 8.00; found: C 49.84, H 7.37, N 14.62, P 8.26.

1,1 -Bis(dimethylamino)- $N, N$-dimethyl- $N^{\prime}$-(4-mesityl)phosphinecarboximidamide selenide $(\mathbf{5 b})$ : To a frozen solution of $\mathrm{PCl}_{3}(0.27 \mathrm{~g}, 2 \mathrm{mmol})$ in benzene $(2 \mathrm{~mL})$, a solution of $C$-silylformamidine $4 \mathbf{b}(0.61 \mathrm{~g}, 1.9 \mathrm{mmol})$ in benzene $(4 \mathrm{~mL})$ was added with stirring. In $1 \mathrm{~h}$, the reaction mixture was concentrated under vacuum. Benzene $(3 \mathrm{~mL})$ was added to the residue, and then, a solution of dimethylamine $(0.41 \mathrm{~g}$, $9 \mathrm{mmol})$ in benzene $(3 \mathrm{~mL})$ was added. The mixture was stirred for $15 \mathrm{~min}$, and then, selenium $(1.9 \mathrm{mmol})$ was added in two portions over $10 \mathrm{~min}$. The resulting suspension was stirred overnight. The insolubles were filtered off and washed with benzene $(2 \times 2 \mathrm{~mL})$, and the filtrate was evaporated. The residue was extracted with hexane $(2 \times 5 \mathrm{~mL})$, the solvent was removed under reduced pressure, and the residual solid was purified by silica gel plate chromatography. Yield, $49 \%$. $R_{\mathrm{f}} 0.5-0.8\left(\mathrm{CH}_{2} \mathrm{Cl}_{2}\right.$-hexane $\left.1: 1\right)$; m.p. $157-158^{\circ} \mathrm{C}$ (pentane); ${ }^{31} \mathrm{P} \quad \mathrm{NMR} \quad\left\{{ }^{1} \mathrm{H}\right\} \quad\left(202 \mathrm{MHz}, \quad \mathrm{CDCl}_{3}\right): \quad \delta \quad 60.0 \mathrm{ppm}$ $\left(J_{\mathrm{PSe}}=793 \mathrm{~Hz}\right) .{ }^{1} \mathrm{H} \mathrm{NMR}\left(300 \mathrm{MHz}, \mathrm{CDCl}_{3}\right): \delta=1.38(\mathrm{~d}$, $\left.J=6.3 \mathrm{~Hz}, 12 \mathrm{H}, \mathrm{CH}_{3}\right), 2.13\left(\mathrm{~s}, 6 \mathrm{H}, \mathrm{CH}_{3}\right), 2.20\left(\mathrm{~s}, 3 \mathrm{H}, \mathrm{CH}_{3}\right)$, 2.50 (d, J = $10 \mathrm{~Hz}, 12 \mathrm{H}, \mathrm{NCH}_{3}$ ), 4.36 (br s, $\left.2 \mathrm{H}, \mathrm{CH}\right), 6.78$ (s, $2 \mathrm{H}, \mathrm{CH}) \mathrm{ppm} ;{ }^{13} \mathrm{C} \mathrm{NMR}\left(125.7 \mathrm{MHz}, \mathrm{CDCl}_{3}\right): \delta=19.1(\mathrm{~s}$, $\left.\mathrm{CH}_{3}\right), 20.2\left(\mathrm{~s}, \mathrm{CH}_{3}\right), 21.2\left(\mathrm{~s}, \mathrm{CH}_{3}\right), 37.8(\mathrm{~s}, \mathrm{CH}), 48.7\left(\mathrm{~s}, \mathrm{CH}_{3}\right)$, 124.75 (s, ipso-C), 127.8 (ipso-C), 127.9 (s, CH), 143.8 (d, $J=8.8 \mathrm{~Hz}$, ipso-C), 145.8 (d, $J=88 \mathrm{~Hz}, \mathrm{~N}=\mathrm{C}$ ); EI-MS 44598.2\% $[M+2]^{+}$; elemental analysis calcd (\%) for $\mathrm{C}_{20} \mathrm{H}_{37} \mathrm{~N}_{4} \mathrm{PSe}$ (443.48): C 54.17, $\mathrm{H}$ 8.41, N 12.63, P 6.98; found: C 53.89, H 8.88, N 13.01, P 7.32.

General procedure for synthesis of compounds ( $6 \mathbf{a}$ and b): To a solution of phosphineselenide 7 (1.9 mmol) in benzene $(4 \mathrm{~mL})$, a solution of tris(morpholino)phosphine $(2 \mathrm{mmol})$ in benzene $(8 \mathrm{~mL})$ was added. The reaction mixture was stirred for $30 \mathrm{~min}$, and then, the solvent was removed under reduced pressure until dryness. The residue was dissolved in pentane $(10 \mathrm{~mL})$, and the obtained solution was cooled to $-12^{\circ} \mathrm{C}$. After several hours, the precipitated solid was filtered off, the filtrate evaporated under vacuum, and the residue distilled to produce compound $\mathbf{6}$.

1,1-Bis(dimethylamino)- $N, N$-dimethyl- $N^{\prime}$-mesityl-

phosphine-carboximidamide (6a): Yield, 93\%. B.p. $120-122^{\circ} \mathrm{C} / 0.05$ Torr; m.p. $26-28^{\circ} \mathrm{C}$; ${ }^{31} \mathrm{P}$ NMR $(81 \mathrm{MHz}$, $\left.\mathrm{CDCl}_{3}\right): \delta=92.4,88.7(10: 1) \mathrm{ppm} ;{ }^{1} \mathrm{H} \mathrm{NMR}(300 \mathrm{MHz}$, $\left.\mathrm{C}_{6} \mathrm{D}_{6}\right): \delta=2.22\left(\mathrm{~s}, 6 \mathrm{H}, \mathrm{CH}_{3}\right), 2.27\left(\mathrm{~s}, 3 \mathrm{H}, \mathrm{CH}_{3}\right), 2.57(\mathrm{~s}, 6 \mathrm{H}$, $\left.\mathrm{NCH}_{3}\right)$ and $2.64\left(\mathrm{~d}, J=8.7 \mathrm{~Hz}, 12 \mathrm{H}, \mathrm{NCH}_{3}\right), 6.86(\mathrm{~s}, 2 \mathrm{H}$, $\mathrm{CH}) \mathrm{ppm} ;{ }^{13} \mathrm{C} \mathrm{NMR}\left(125.7 \mathrm{MHz}, \mathrm{C}_{6} \mathrm{D}_{6}\right) \delta=18.8\left(\mathrm{~s}, \mathrm{CH}_{3}\right)$, $20.2\left(\mathrm{~s}, \mathrm{CH}_{3}\right), 38.1$ (d, J=10 Hz, $\left.\mathrm{CH}_{3}\right), 40.6$ (d, $J=15 \mathrm{~Hz}$, $\mathrm{CH}_{3}$ ), 125.3 (s, ipso-C), 127.7 (s, CH), 127.9 (s, ipso-C), 147.3 (s, ipso-C), 160.0 (d, $J=15 \mathrm{~Hz}, \mathrm{~N}=\mathrm{C})$; elemental analysis calcd (\%) for $\mathrm{C}_{16} \mathrm{H}_{29} \mathrm{~N}_{4} \mathrm{P}$ (308.4): C 62.31, H 9.48, N 18.17, P 10.04; found: C 62.02, H 9.71, N 18.42, P 9.86.

1,1-Bis(dimethylamino)- $N, N$-diisopropyl- $N^{\prime}$-mesitylphosphine-carboximidamide (6b): Yield, $98 \%$. B.p. $130^{\circ} \mathrm{C} /$
0.05 Torr, m.p. $59-60^{\circ} \mathrm{C}$ (pentane, $\left.-28^{\circ} \mathrm{C}\right) ;{ }^{31} \mathrm{P}$ NMR $(81 \mathrm{MHz}$, $\left.\mathrm{CDCl}_{3}\right): \delta=90.1 \mathrm{ppm} ;{ }^{1} \mathrm{H}$ NMR $\left(500 \mathrm{MHz}, \mathrm{C}_{6} \mathrm{D}_{6}\right): \delta=1.34(\mathrm{br}$ s, $12 \mathrm{H}, \mathrm{CH}_{3}$ ), 2.26 (s, $\left.6 \mathrm{H}, \mathrm{CH}_{3}\right), 2.27$ (s, $\left.3 \mathrm{H}, \mathrm{CH}_{3}\right), 2.34$ (d, $\left.J=8.5 \mathrm{~Hz}, 12 \mathrm{H}, \mathrm{NCH}_{3}\right), 3.93$ (br s, $\left.2 \mathrm{H}, \mathrm{CH}\right), 6.85$ (s, $\left.2 \mathrm{H}, \mathrm{CH}\right)$ ppm; ${ }^{13} \mathrm{C}$ NMR $\left(125.7 \mathrm{MHz}, \mathrm{C}_{6} \mathrm{D}_{6}\right): 19.1\left(\mathrm{~d}, J=4 \mathrm{~Hz}, \mathrm{CH}_{3}\right), 20.2$ (s, $\left.\mathrm{CH}_{3}\right), 20.9$ (s, $\left.\mathrm{CH}_{3}\right), 40.9$ (d, J=15 Hz, CH3), 47.8 (d, $J=13 \mathrm{~Hz}, \mathrm{CH}), 124.1$ (s, ipso-C), 126.0 (s, ipso-C), 127.9 (s, CH), 145.9 (s, ipso-C), 157.5 (d, $J=40 \mathrm{~Hz}, \mathrm{~N}=\mathrm{C}$ ); elemental analysis calcd (\%) for $\mathrm{C}_{20} \mathrm{H}_{37} \mathrm{~N}_{4} \mathrm{P}$ (364.52): C 65.90, $\mathrm{H}$ 10.23, N 15.37, P 8.50; found: C 66.32, H 9.97, N 15.67, P 8.31.

1,1-Dichloro- $N, N$-diisopropyl- $N$ '-mesityl-phosphinecarboximidamide (7b): To a solution of $\mathbf{6 b}(360 \mathrm{mg}, 1 \mathrm{mmol})$ in benzene $(4 \mathrm{~mL}), \mathrm{PCl}_{3}(305 \mathrm{mg}, 2.2 \mathrm{mmol})$ was added. The reaction mixture was stirred at $20^{\circ} \mathrm{C}$ for $25 \mathrm{~min}$ and then concentrated under vacuum. The oily residue was kept at $60^{\circ} \mathrm{C}$ under vacuum for $25 \mathrm{~min}$ and then distilled, b.p. $120^{\circ} \mathrm{C} /$ 0.05 Torr to give $7 \mathbf{b}$ of $340 \mathrm{mg}(99 \%) .{ }^{31} \mathrm{P} \mathrm{NMR}(81 \mathrm{MHz}$, $\left.\mathrm{C}_{6} \mathrm{D}_{6}\right): \delta=134.1 \mathrm{ppm} ;{ }^{1} \mathrm{H}$ NMR $(300 \mathrm{MHz}, \mathrm{C} 6 \mathrm{D} 6): \delta=1.30$ $\left(\mathrm{d}, J=5.4 \mathrm{~Hz}, 12 \mathrm{H}, \mathrm{CH}_{3}\right), 2.16+2.18\left(2^{\mathrm{x}} \mathrm{s}, 9 \mathrm{H}, \mathrm{CH}_{3}\right), 4.03(\mathrm{br}$ s, $2 \mathrm{H}, \mathrm{CH}), 6.78(\mathrm{~s}, 2 \mathrm{H}, \mathrm{CH}) \mathrm{ppm} ;{ }^{13} \mathrm{C} \mathrm{NMR}(125.7 \mathrm{MHz}$, $\left.\mathrm{C}_{6} \mathrm{D}_{6}\right): \delta=18.6\left(\mathrm{~d}, J=2.5 \mathrm{~Hz}, \mathrm{CH}_{3}\right), 19.8\left(\mathrm{~s}, \mathrm{CH}_{3}\right), 20.2(\mathrm{~s}$, $\mathrm{CH}_{3}$ ), 48.6 (s, CH), 125.0 (s, i-C), 128.3 (s, CH), 131.2 (s, i-C), 143.6 (d, J=30 Hz, i-C), 154.1 (d, $J=99 \mathrm{~Hz}, \mathrm{C}=\mathrm{N})$; elemental analysis calcd (\%) for $\mathrm{C}_{16} \mathrm{H}_{25} \mathrm{Cl}_{2} \mathrm{~N}_{2} \mathrm{P}$ (347.27): $\mathrm{Cl}$ 20.42, P 8.92; found: Cl 20.06, P 9.05.

Dichlorophosphoranide (9): To a solution of silylformamidine 8 (1.0 g, $4.5 \mathrm{mmol})$ and $\mathbf{1}(670 \mathrm{mg}, 4.5 \mathrm{mmol})$ in $\mathrm{CH}_{2} \mathrm{Cl}_{2}(10 \mathrm{~mL})$, cooled to freezing, $\mathrm{PCl}_{3}(730 \mathrm{mg}, 5.3 \mathrm{mmol})$ was added. The reaction mixture was allowed to warm at ambient temperature $\left(16^{\circ} \mathrm{C}\right)$ with stirring. The solvent was removed under vacuum. The residue was extracted with $\mathrm{Et}_{2} \mathrm{O}(15 \mathrm{~mL})$. The insoluble powder was filtered under argon, washed with $\mathrm{Et}_{2} \mathrm{O}(3 \times 10 \mathrm{~mL})$, and dried under vacuum. The collected solid was shaken in THF $(26 \mathrm{~mL})$, insoluble part was collected by filtration and washed with THF ( $5 \mathrm{~mL})$, and the filtrate was evaporated under vacuum. The residue was recrystallized from $\mathrm{CH}_{3} \mathrm{CN}(7 \mathrm{~mL})$ to give 9 of $330 \mathrm{mg}$ (18\%). M.p. $141-144^{\circ} \mathrm{C}$ (decomp); ${ }^{31} \mathrm{P} \mathrm{NMR}$ $\left(202 \mathrm{MHz}, \mathrm{CDCl}_{3}\right): \delta=124.7 \mathrm{ppm} .{ }^{1} \mathrm{H} \mathrm{NMR}(500 \mathrm{MHz}$, $\mathrm{C}_{6} \mathrm{D}_{6}$ ): $\delta=1.23$ (br s, $6 \mathrm{H}, \mathrm{CH}_{3}$ ), 2.49 (br s, $6 \mathrm{H}, \mathrm{CH}_{3}$ ), 4.67 (br s, $1 \mathrm{H}, \mathrm{CH}$ ), 7.07 (br s, $6 \mathrm{H}, \mathrm{Ph}$ ), 8.26 (br s, $4 \mathrm{H}, \mathrm{Ph}$ ). Elemental analysis calcd (\%) for $\mathrm{C}_{18} \mathrm{H}_{23} \mathrm{Cl}_{2} \mathrm{~N}_{4} \mathrm{P}$ (397.29): $\mathrm{Cl}$ 17.85, P 7.80; found: $\mathrm{Cl} 18.11, \mathrm{P} 7.69$.

Chlorophosphine (10): To a solution of silylformamidine $4 \mathrm{a}(0.96 \mathrm{~g}, 3.7 \mathrm{mmol})$ in benzene $(2.5 \mathrm{~mL})$, phosphorus trichloride $(0.25 \mathrm{~g}, 1.8 \mathrm{mmol})$ in benzene $(1 \mathrm{~mL})$ was added. A slight exothermic effect was observed. In $1 \mathrm{~h}$, all solvents evaporated to give a white solid. ${ }^{31} \mathrm{P}$ NMR $(202 \mathrm{MHz}$, $\left.\mathrm{CDCl}_{3}\right): \delta=30$ ppm [7].

Dichlorophosphoranide (11): To a solution of chlorophosphine $10(0.6 \mathrm{~g}, 1.4 \mathrm{mmol})$ in benzene $(5 \mathrm{~mL})$, a solution of hydrogen chloride $(0.05 \mathrm{~g}, 1.4 \mathrm{mmol})$ in ether $(3 \mathrm{~mL})$ was added. The precipitated solid was collected by filtration. The solid was washed with ether. The solid was recrystallized from benzene to give white crystals of $0.52 \mathrm{~g}$, 80\%. M.p. $\quad 181-182^{\circ} \mathrm{C} .{ }^{31} \mathrm{P}$ NMR (81 $\left.\mathrm{MHz}, \mathrm{CDCl}_{3}\right)$ : $\delta=-102 \mathrm{ppm}$; elemental analysis calcd (\%) for $\mathrm{C}_{24} \mathrm{H}_{35} \mathrm{Cl}_{2} \mathrm{~N}_{4} \mathrm{P}$ (481.45): $\mathrm{Cl} 14.73, \mathrm{P}$ 6.43; found: $\mathrm{Cl} 14.38, \mathrm{P}$ 6.04 . 


\section{Results and Discussion}

We started the synthesis of derivatives bearing one formamidine substituent. Thus, compounds $\mathbf{4 a}$ and $\mathbf{b}$ react consecutively with phosphorus trichloride, dimethylamine, and selenium in a one-pot procedure affording stable derivatives $\mathbf{5} \mathbf{a}$ and $\mathbf{b}$ which were isolated and fully characterized. Phosphineselenides $\mathbf{5 a}$ and $\mathbf{b}$ were purified by silica gel plate chromatography. Phosphineselenides 5a and $\mathbf{b}$ were reduced by tris(morpholino)phosphine to give phosphonous diamides $\mathbf{6 a}$ and $\mathbf{b}$. They are stable, distillable in high-vacuum compounds. While the ${ }^{31} \mathrm{P}$ NMR spectrum of highly sterically hindered compound $\mathbf{6 b}$ involves only one signal at $90.1 \mathrm{ppm}$, compound 6a exhibits two signals at 92.4 and $88.7 \mathrm{ppm}$ in a ratio $10: 1$ corresponding to syn/antiisomers. The reaction of phosphonous diamide $\mathbf{6 b}$ with phosphorus trichloride in a $1: 2$ ratio produced dichlorophosphine $7 \mathbf{b}\left(\delta_{\mathrm{p}}=134 \mathrm{ppm}\right)$, which was isolated by distillation as an individual compound (Scheme 2). The compound is stable in the solid state, but in solution, it decomposes quite promptly, in a few hours. Monitoring this process by ${ }^{31} \mathrm{P}$ NMR reveals formation of numerous signals including phosphorus trichloride. The reaction of phosphonous diamide $\mathbf{6 a}$ under the same conditions also afforded dichlorophosphine $7 \mathbf{a}$, which cannot be isolated as a pure compound, but it is possible to obtain its derivatives. The method of dichlorophosphine synthesis being available, it was possible to validate the proposed mechanism for the formation of dibromophosphoranide (Scheme 1). It is known that formamidines do not react with phosphorus trichloride. It allowed us to carry out a three-component reaction of formamidine $\mathbf{1}$, its trimethylsilylated derivative $\mathbf{8}$ with phosphorus trichloride. Initially, $\mathrm{PCl}_{3}$ would react with silylated formamidine $\mathbf{8}$ to form the corresponding dichlorophosphine, which, according to the proposed mechanism, should react with formamidine $\mathbf{1}$ to form dichlorophosphoranide $\mathbf{9}$ in the next stage (Scheme 3).

Indeed, by adding phosphorus trichloride to a mixture of formamidine $\mathbf{1}$ and its silylated derivative $\mathbf{8}$, the target dichlorophosphoranide 9 was prepared. The reaction mixture was monitored by ${ }^{31} \mathrm{P}$ NMR spectroscopy, and it exhibited only one ${ }^{31} \mathrm{P}$ NMR signal at $124 \mathrm{ppm}$. Nevertheless, we separated phosphoranide 9 only during $18 \%$ yield. Its structure was confirmed by X-ray diffractometry. Compound 9 crystallizes in the space group $\mathrm{P}^{-1}$ with 2 molecules in the unit cell. Figure 2 shows the molecular structure and contains key interatomic distances and bond angles.

The molecular structure of $\mathbf{9}$ shows a distorted, $\psi$-trigonal bipyramidal coordination of the $\mathrm{P}$ atom. Two chlorine atoms occupy the axial positions, while a lone electron pair and the cycle are located in the equatorial positions. The $\mathrm{P}-\mathrm{Cl}$ bond lengths in dichlorophosphoranide $\mathbf{9}$ are very different (P1-Cl1 2.8509(6) $\AA$; P1-Cl2 2.2058(6) $)$ ). The second value is close to $\mathrm{P}-\mathrm{Cl}$ bond lengths ranging from 2.295 to $2.469 \AA$ in related phosphorus compounds, and the first value is far beyond that range and is intermediate between the covalent $\mathrm{P}-\mathrm{Cl}$ bond and cationic-anionic distances in crystals $[4,10]$. In comparison, the $\mathrm{P}-\mathrm{Br}$ bond lengths in dibromophosphoranide 3 are very similar in length: $2.6945(16)$ and 2.5792(15) $\AA$. Other structural
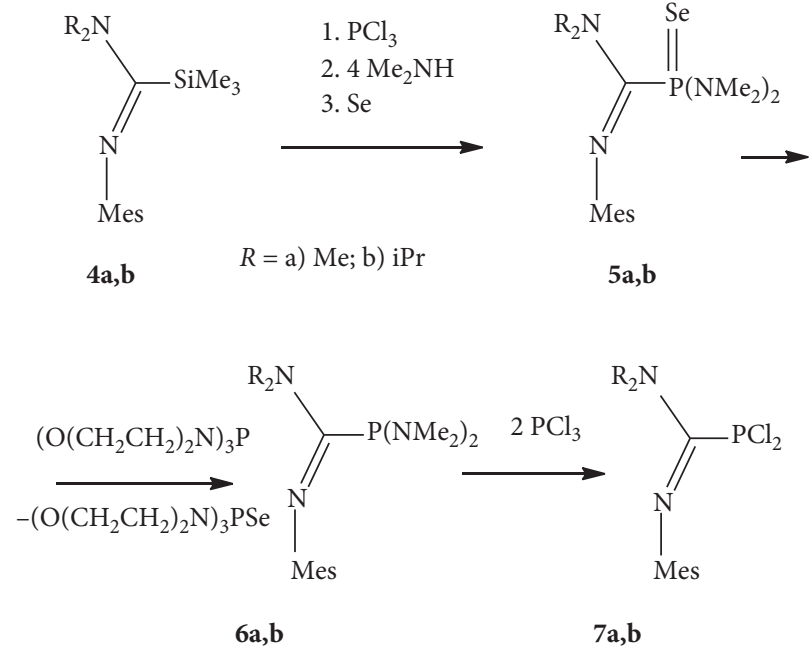

Scheme 2: Synthesis of dichlorophosphines and their derivatives.

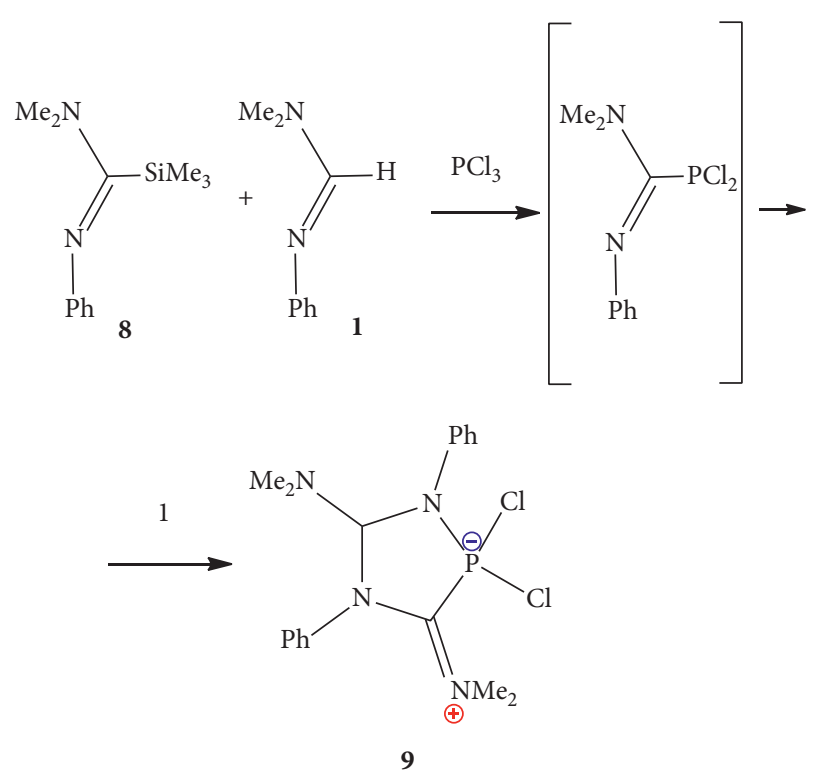

Scheme 3: Synthesis of dichlorophosphoranide 9.

parameters of both phosphoranides 3 and 9 are quite close. ${ }^{31} \mathrm{P}$ NMR chemical shifts of phosphoranide $3\left(\delta_{\mathrm{p}}=56.8 \mathrm{ppm}\right.$ in $\left.\mathrm{CDCl}_{3}\right)$ and $\mathbf{9}\left(\delta_{\mathrm{p}}=124.7 \mathrm{ppm}\right.$ in $\left.\mathrm{CDCl}_{3}\right)$ are indicative of their phosphoranide structures. While a high-field shift of phosphoranide 3 testifies that in a solution, it does not dissociate, a low-field shift of phosphoranide 9 attests to a high degree of dissociation. An analogous acyclic dichlorophosphoranide $\left(\delta_{\mathrm{p}}=92.3 \mathrm{ppm}\right.$ in $\left.\mathrm{CDCl}_{3}\right)$ was prepared by addition of 2,2,6,6tetramethylpiperidinedichlorophosphine to cyclic (alkyl)(amino)carbene. Although X-ray was not available, it was presented as a phosphonium salt [11].

In our previous work, we have shown that silylformamidine 4a reacts with phosphorus trichloride in a 2:1 ratio producing chlorophosphine 10 [7].

Monitoring by ${ }^{31} \mathrm{P}$ NMR, a solution of chlorophosphine $\mathbf{1 0}$ $\left(\delta_{\mathrm{p}}=31 \mathrm{ppm}\right)$ showed that its signal gradually disappears and a signal in a strong field $\left(\delta_{\mathrm{p}}=-102 \mathrm{ppm}\right)$ grows, which became 


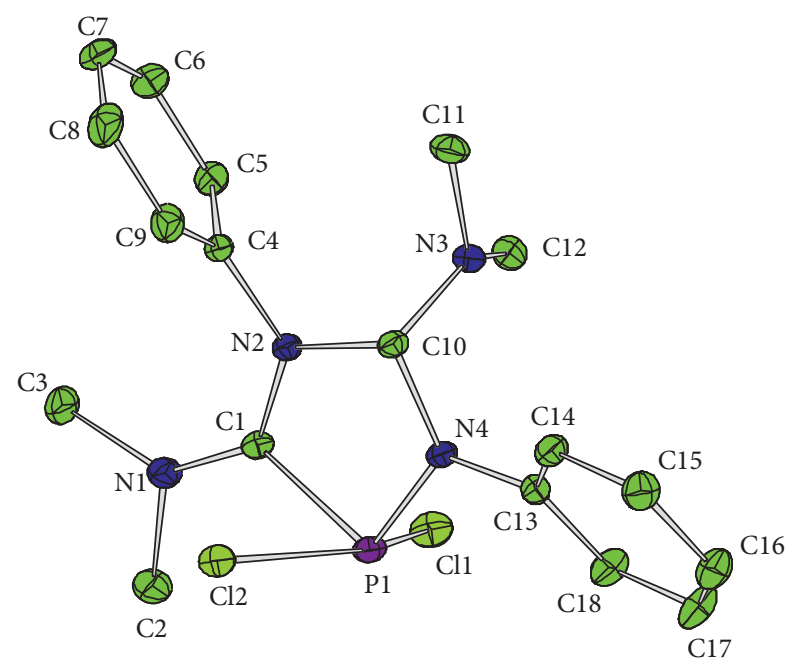

Figure 2: The perspective view of the molecule 9 with 50\% probability ellipsoids for non- $\mathrm{H}$-atoms. The selected bond lengths ( $\AA$ ) and angles $\left({ }^{\circ}\right)$ : $\mathrm{Cl}(1)-\mathrm{P}(1) 2.2058(6), \mathrm{Cl}(2)-\mathrm{P}(1) 2.8509(6), \mathrm{P}(1)-$ $\mathrm{N}(4)$ 1.6621(13), $\mathrm{P}(1)-\mathrm{C}(1)$ 1.8501(15), N(1)-C(1) 1.313(2), N(2)C(1) 1.3255(19), N(2)-C(10) 1.5135(18), N(3)-C(10) 1.4115(19), $\mathrm{N}(4)-\mathrm{C}(10) \quad 1.4624(19) ; \quad \mathrm{N}(4) \mathrm{P}(1) \mathrm{C}(1) \quad 89.10(7), \quad \mathrm{P}(1) \mathrm{C}(1) \mathrm{N}(2)$ 110.67(11), C(1)N(2)C(10) 116.88(12), N(2)C(10)N(4) 103.16(11), $\mathrm{P}(1) \mathrm{N}(4) \mathrm{C}(1) \cdot 119.37(10)$.

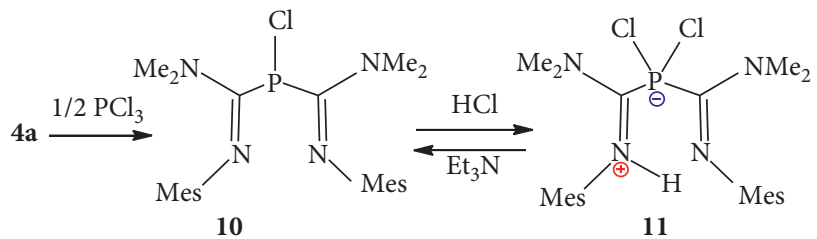

Scheme 4: Synthesis of dichlorophosphoranide 11.

predominant over time. When triethylamine was added to the solution, the signal $\left(\delta_{\mathrm{p}}=-102 \mathrm{ppm}\right)$ disappeared and the signal of chlorophosphine $\mathbf{1 0}$ was restored. We carried out a quantitative experiment in which an equivalent amount of hydrogen chloride was added to a solution of chlorophosphine 10. It transformed into dichlorophosphoranide 11(Scheme 4). The reaction is reversible and, when triethylamine is added, phosphoranide $\mathbf{1 1}$ is converted to chlorophosphine $\mathbf{1 0}$. The molecular structure of phosphoranide $\mathbf{1 1}$ was unambiguously determined by single-crystal X-ray diffractometry (Figure 3 ). Compound 11 crystallizes in the Pna21 space group with 4 molecules in the unit cell. Figure 3 shows that the molecular structure contains some interatomic distances and bond angles. The molecular structure of phosphoranide $\mathbf{1 1}$ shows that $\mathrm{P}-\mathrm{Cl}$ bond lengths are almost the same $(\mathrm{Cl}(1)-$ $\mathrm{P}$ (1) 2.3444(9), $\mathrm{Cl}(2)-\mathrm{P}(1)$ 2.3303(9) $⿱$ ). The ${ }^{31} \mathrm{P}$ resonance of $11\left(\delta_{\mathrm{p}}=-102 \mathrm{ppm}\right.$ in $\left.\mathrm{CDCl}_{3}\right)$ is substantially shifted to a higher field, but it is very close to that of the related phosphoranide $\mathrm{C}\left(\delta_{\mathrm{p}}=-98.9 \mathrm{ppm}\right.$ in $\left.\mathrm{CD}_{2} \mathrm{Cl}_{2}\right)$. Such a substantial highfield shift correlates with a smaller degree of dissociation into phosphine and hydrogen chloride $[12,13]$. CCDC $1938108(\mathbf{9})$ and 1938107 (11) contain the supplementary crystallographic data for this paper.

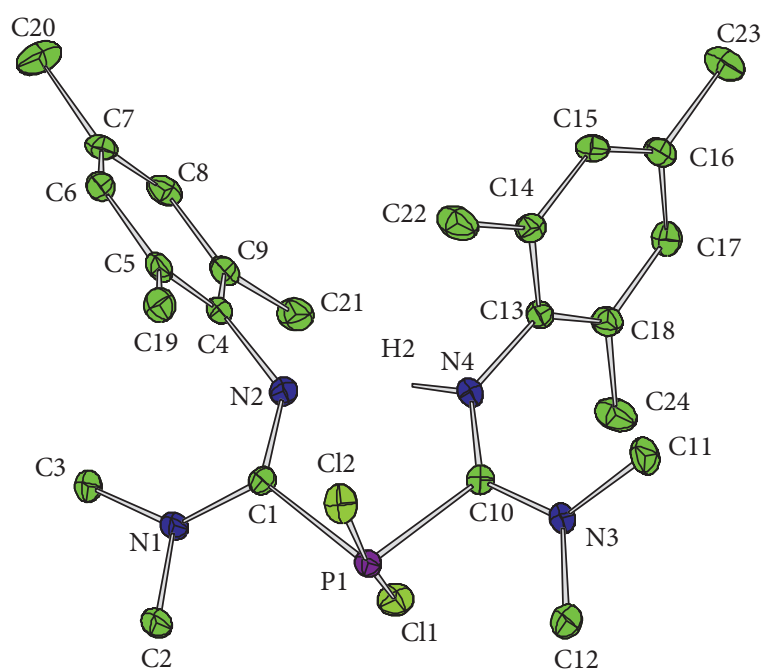

FIgURE 3: The perspective view of the molecule 11 with $50 \%$ probability ellipsoids for non-H-atoms. The selected bond lengths $(\AA)$ and angles $\left({ }^{\circ}\right)$ : $\mathrm{Cl}(1)-\mathrm{P}(1)$ 2.3444(9), $\mathrm{Cl}(2)-\mathrm{P}(1)$ 2.3303(9), $\mathrm{P}(1)-$ $\mathrm{C}(1)$ 1.893(2), $\mathrm{P}(1)-\mathrm{C}(10)$ 1.887(2), N(1)-C(1) 1.331(3), N(2)-C(1) 1.296(3), N(3)-C(10) 1.342(3), N(4)-C(10) 1.292(3); C(1)P(1)C(10) 103.99(10), $\mathrm{N}(1) \mathrm{C}(1) \mathrm{N}(2)$ 128.2(2), N(3)C(10)N(4) 127.4(2).

\section{Conclusions}

We confirmed experimentally the mechanism for formation of dichloro(dibromo)-phosphoranides 3 and $\mathbf{9}$ previously proposed on the basis of DFT calculations. Dichlorophosphoranide 9 was prepared by a threecomponent reaction between $C$-trimethylsilyl- $N, N$-dimethyl- $N^{\prime}$-phenylformamidine, $\quad N, N$-dimethyl- $N^{\prime}$-phenylformamidine, and phosphorus trichloride. At first, $C$ trimethylsilyl- $N, N$-dimethyl- $N^{\prime}$-phenylformamidine reacts with phosphorus trichloride to give the corresponding dichlorophosphine bearing the formamidine substituent, followed by addition of $N, N$-dimethyl- $N^{\prime}$ phenylformamidine to afford the target dichlorophosphoranide 9. It was shown that chlorophosphine $\mathbf{1 0}$ reacts with hydrogen chloride to form dichlorophosphoranide 11. In the presence of triethylamine, the reaction is reversible and gives chlorophosphine 10. The molecular structures of phosphoranides $\mathbf{9}$ and $\mathbf{1 1}$ were determined by single-crystal X-ray diffractometry.

\section{Data Availability}

The ${ }^{1} \mathrm{H},{ }^{13} \mathrm{C},{ }^{31} \mathrm{P}$ NMR instrumental data and elemental analysis data used to support the findings of this study are included within the article.

\section{Conflicts of Interest}

The authors declare that they have no conflicts of interest.

\section{Supplementary Materials}

The supplementary materials contain copies of ${ }^{1} \mathrm{H}$ and ${ }^{13} \mathrm{C}$ NMR spectra. (Supplementary Materials) 


\section{References}

[1] K. B. Dillon, A. W. G. Platt, A. Schmidpeter, F. Zwaschka, and W. S. Sheldrick, "Tetrachloro- und Tricyanochlorophosphat(III) Strukturbilder einer auf halbem Wege stehengebliebenen Addition," Zeitschrift für anorganische und allgemeine Chemie, vol. 488, no. 1, pp. 7-26, 1982.

[2] W. S. Sheldrick, A. Schmidpeter, F. Zwaschka, K. B. Dillon, A. W. G. Platt, and T. C. Waddington, "The structures of hypervalent phosphorus(III) anions $\mathrm{P}(\mathrm{CN})_{4-\mathrm{n}} \mathrm{Brn}^{-}$. Transition from $\psi$-trigonal-bipyramidal to $\psi$-octahedral co-ordination and deviation from Valence Shell Electron Pair Repulsion Theory," Journal of the Chemical Society, Dalton Transactions, vol. 2, pp. 413-418, 1981.

[3] K. O. Christe, D. A. Dixon, H. P. A. Mercier, J. C. P. Sanders, G. J. Schrobilgen, and W. W. Wilson, "Tetrafluorophosphite, PF4-, anion," Journal of the American Chemical Society, vol. 116, no. 7, pp. 2850-2858, 1994.

[4] K. Schwedtmann, M. H. Holthausen, K.-O. Feldmann, and J. J. Weigand, "NHC-mediated synthesis of an asymmetric, cationic phosphoranide, a phosphanide, and coinage-metal phosphanido complexes," Angewandte Chemie International Edition, vol. 52, no. 52, pp. 14204-14208, 2013.

[5] Y. Wang, Y. Xie, M. Y. Abraham et al., "Carbene-stabilized parent phosphinidene†," Organometallics, vol. 29, no. 21, pp. $4778-4780,2010$.

[6] A. P. Marchenko, G. N. Koidan, A. N. Hurieva, A. B. Rozhenko, and A. N. Kostyuk, "Zwitterionic phosphoranides as intermediates in the reaction of phosphorus tribromide with $\mathrm{N}, \mathrm{N}$-dimethyl- $\mathrm{N}^{\prime}$-arylformamidines," Heteroatom Chemistry, vol. 27, no. 1, pp. 12-22, 2016.

[7] A. Marchenko, G. Koidan, A. Hurieva, Y. Vlasenko, and A. Kostyuk, "C-Silyl- $N, N$-dialkyl- $N$ '-arylformamidines: synthesis and reactions with phosphorus(III) chlorides," European Journal of Inorganic Chemistry, vol. 2016, no. 29, pp. 4842-4849, 2016.

[8] A. Altomare, M. C. Burla, M. Camalli et al., "SIR97: a new tool for crystal structure determination and refinement," Journal of Applied Crystallography, vol. 32, no. 1, pp. 115-119, 1999.

[9] P. W. Betteridge, J. R. Carruthers, R. I. Cooper, K. Prout, and D. J. Watkin, "CRYSTALSversion 12: software for guided crystal structure analysis," Journal of Applied Crystallography, vol. 36, no. 6, p. 1487, 2003.

[10] T. Böttcher, B. S. Bassil, L. Zhechkov, T. Heine, and G.-V. Röschenthaler, "( $\left(\mathrm{NHC}^{\mathrm{Me}}\right) \mathrm{SiCl}_{4}$ : a versatile carbene transfer reagent-synthesis from silicochloroform," Chemical Science, vol. 4, no. 1, pp. 77-83, 2013.

[11] O. Back, M. A. Celik, G. Frenking, M. Melaimi, B. Donnadieu, and G. Bertrand, "A crystalline phosphinyl radical cation," Journal of the American Chemical Society, vol. 132, no. 30, pp. 10262-10263, 2010.

[12] K. B. Dillon, "Phosphoranides," Chemical Reviews, vol. 94, no. 5, pp. 1441-1456, 1994.

[13] J. G. Verkade and L. D. Quin, Phosphorus-31 NMR Spectroscopy in Stereochemical Analysis, VCH, Deerfield Beach, FL, USA, 1987. 